Capital Allocation Efficiency, SOEs Reform and China's Economic Growth

Zhao LI, School of Economic \& Management, Tongji University

Ji Shi Building 216, Cao-an Road 4800, Shanghai, 201800

Tel:18702103720; Email: lizhao021@163.com 


\title{
Capital Allocation Efficiency, SOEs Reform and China's Economic Growth
}

\begin{abstract}
This paper studies the mechanism of how China's state-owned enterprise (SOEs) reform can influences economic growth, and distinguishes the capital efficiency between state-owned and private enterprises. The results show that: 1) the capital allocation efficiency among state-owned enterprises is lower than private enterprise due to an insufficiently released productivity of state-owned enterprises; 2 ) although with a higher capital allocation efficiency, the improvement of technology progress of private enterprises at a much slower pace compared to its rapidly increasing share in China's economy. In case of poor allocation with private sector, blindly reforming ownership of state-owned enterprises cannot effectively alleviate the problem of efficiency losses. State-owned enterprise reform can boost economic growth by increasing capital marginal output, improving capital dynamic allocation efficiency, promoting TFP growth and exerting external spillovers on other firms. At present, China is exploring the endogenous power of economic growth, improving the market institutions and promoting the stateowned enterprises reform with positive and steady pace. By properly re-allocation SOEs into the private sector, which has significant influence on improving economic efficiency and promoting sustained economic growth.
\end{abstract}

Key words: ownership reform; capital allocation; economic growth; total factors production

\section{Introduction}

After a long period of fast-paced economic growth, China has entered the "new normal" era of medium-speed development. It is facing the decline of the capital accumulation rate, the disappearance of low labor cost and the diminish of technological progress through "learn by doing". Currently, the factor allocation efficiency and technological innovation are hindered by the current economic structure and institutional structure, which made it difficult to reverse the trend of economic growth slowdown via the improvement of production efficiency. In order to release the economic vitality, China needs to further deepening the reform of economic institutions, whose core is state-owned enterprise (SOEs) reform. SOEs reform in China has attracted a number of researches. The results mainly focus on the following three aspects. Firstly, some studies found that by comparing the production efficiency between state-owned enterprises and private enterprises, the production efficiency of state-owned enterprises is relatively low, and the productivity of stated-owned enterprises has not reached its fully potential (Liu. et al., 2004; Brandt. et al, 2012; Mu, 2012). Secondly, the empirical analysis of the economic effect of SOEs reform, most found that SOEs reform promoted the production efficiency to a certain extent. The reform can enhance economic growth through raising marginal output of capital, improving allocation efficiency of capital, increasing TFP growth rate and exerting the spillover effect on other firms (Bai. et al., 2006; Hu. et al., 2006). Lastly, for those exploring the reasons for the low efficiency of state-owned enterprises, there are serious issues of factors misallocation in China (Hsieh and Klenow, 2009), ownership discrimination in financial sector when Chinese banks allocated capitals with increasing biases toward SOEs (Song. etc., 2011; Wu, 2015; Xu. et al., 2015), and stated-owned enterprises large corporate debt (Zhong. et al, 2016).

Some scholars thought the ownership reform would alleviate the efficiency loss caused by stateowned enterprises (Zhang. et al., 2016); however, the existing literatures are mostly concerned about the productivity efficiency of state-owned enterprises in comparison to non-state-owned enterprises from 
micro-enterprise, which ignored the direct link between SOEs reform and economic growth. Besides, because of the imperfect market economy, private enterprises maybe also have the problem of low factors allocation efficiency within the sector. In order to better promote further economic and deepening, it is essential to figure out the current main economic problems. The socialist market economy with Chinese characteristics features the coexistence of various forms of ownership while maintain the development of public ownership as the main pillar. A series of SOEs reform, such as "grasp the large, let go of the small", integration and reorganization, establish modern enterprise system, etc., have improved the economic efficiency and the TFP of state-owned enterprises convergence to private enterprises (Hsieh and Song, 2015). Although the transformation of state-owned enterprises into private enterprises would promote economic growth, as a strong foundation of Chinese socialism economic institutions, stateowned enterprises play an important role in sustaining and stabilizing economic growth. In other words, state-owned enterprises cannot simply be replaced by private enterprises. If certain private enterprises also experience poor allocation efficiency, blindly promoting the reform of state-owned enterprises ownership cannot effectively alleviate the problem of efficiency losses. At present, the most urgent issue is to improve the market system and the market function, to eliminate market distortions, and to promote the optimization of the capital allocation mechanism between enterprises is the most urgent issue at present.

Instead of focusing on the micro level as the existing literatures have done, this paper builds a macro economic model between SOEs reform and economic growth, and estimates the influence of SOEs reform on the economic growth rate. By doing so, it not only extends the existing study framework of SOEs reform, but also provides a new perspective on the steady growth in the current situation of economic growth slowdown. The arrangement of the paper is as follows: the first part is the introduction. The second part provides a narrative on the process of SOEs reform. The third part analyses the mechanism between SOEs reform and economic growth. The fourth part focuses on explaining the relationship between SOEs reform and privatization before drawing the conclusion and policy recommendations in the last part.

\section{The Process of SOEs Reform}

Since 1978, China has been going through a series of gradual economic reforms. The traditional state-owned enterprises were given more autonomy in their operations, whereas restrictions on entry of private enterprises were also gradually loosened. The reforms during this period encouraged state-owned enterprises to become more market-oriented. Previous researches proved that productivity efficiency of state-owned enterprises had been improved due to the reforms. Because these measures allowed economic viability to be released, China had a rapidly economic growth until the mid 1990s; however, since then, the state-owned enterprises started to face a decline in productivity efficiency and problems of triangular debt crisis because of the burden of maintain employment stability. Meanwhile, the reform that focused on managerial autonomy also produces a new dilemma for the government- how to balance between managerial autonomy and the control right of the state as the largest stakeholder of state-owned enterprises. In order to solve the problems, China initiated another series reform that allowed state-owned enterprises privatization, namely to allow other shareholders from private sector, in order to encourage state-owned enterprises becoming more market-oriented.

\subsection{The Stage of SOEs Modernization}

From 1993 to 2002, the main efforts of the SOEs reform were to establish a "modern enterprise system". In July 1994, with the Company Law entering into force, the SOEs corporatization has found its legal basis. From that time, the state-owned enterprises were entitled as independent legal entities and 
their supervisors in the past, government agencies, have transferred into their equity holders. In early 1995, China's SOEs reform stimulated a more explicit strategy of "grasp the large, let go of the small", which clarified the reform objectives and stepped to the modern management of state-owned enterprises. "Grasp the large, let go of the small" means to centralize state-owned assets in the industry fields that influence national economy and national security, such as some capital intensive and heavily regulated industries; at the same time, small and medium-sized state-owned enterprises, mainly the local-level state-owned enterprises which had difficulty in management, should quit the market or go bankruptcy via various forms restructuring, such as reorganization, mergers and acquisition, conversion to shareholding companies, or even outright closures. SOEs reform has begun to focus on improving the quality by reducing the number of necessary quantities. The establishment of modern enterprise system is not only complementary to the reform of shareholding system, but also paved the reform of the ownership of state-owned enterprises in the next step.

\subsection{The Stage of SOEs Demutualisation}

From 2003 to 2013, the main efforts of the SOEs reform were to establish a "modern economic market system". In 2003, "The Decision of the Central Committee of the Communist Party of China on Several Issues Concerning the Improvement of the Socialist Market Economic System" adopted by the Third Plenary Session of the 16th CPC Central Committee put forward that "to adapt to the trend of the continuous development of economic market, and further enhance the vitality of the public economy, vigorously develop mixed ownership economy shareholders by state-owned capital, collective capital and non-public capital, to achieve diversification of investment entities, so that the joint stock system to become the main form of public ownership". This is an important measure to further improve China's socialist market economic system, which is of great significance to deepen the reform of market economy system. During this period, the share of SOEs in China's industrial sector shrank steadily as the stateowned enterprises begun to be privatized. In 2003, SOEs and state-holding industrial corporations accounted for $60 \%$ of the total output and $47.9 \%$ of the industrial value-added. By 2013, the figures had reduced to $43.7 \%$ and $24.8 \%$, respectively. The process of privatization brought market competition. As a result, the management efficiency of the state-owned enterprises was improved and the value of national assets were increased, along with the rapid expansion of private sector.

\subsection{The Stage of SOEs Mixed Ownership}

China faces a unique phenomenon that multitask of state-owned enterprises with not only strong incentives for social stability but also interest in the improvement of productivity efficiency, while private enterprises with strong incentives for production have little interest in providing social stability. Consequently, the SOEs reform cannot simply be considered as the process of privatization. The socialist market economy with Chinese characteristics is a dual-track system that requires coexistence of both public and private ownership while taking the public ownership as the supporting pillar. At this stage, "Guojin Mintui" is not an option, nor is the road to full privatization. The development of mixed ownership economy is the most suitable choice. In 2013, "Decision of Some Major Issues of the Central Committee of the Communist Party of China on Deepening the Reform" adopted by the Third Plenary Session of the 18th CPC Central Committee put forward that "consolidate and develop the public economy, adhere to the main body of public ownership, play a leading role in state-owned economy, and continuously enhance the state-owned economic vitality, control, influence. Encourage, support and guide the development of non-public economy, stimulate non-public economic vitality and creativity". Through the development of mixed ownership, Chinese government can combine the scale advantage and talent advantage of state-owned enterprises with institutional advantage and efficiency advantage of private enterprises, and integrate capital to achieve mutual benefit and common development. On the basis to format new competitive advantage of China's enterprises and China's normal economic. 


\section{The Mechanism Between SOEs Reform and Economic Growth}

The SOEs reform in this paper is defined as shared holders reform of state-owned enterprises. It is the process of enterprises solely-controlled by the state accepting shareholders from non-state-owned enterprises. Furthermore, the operating mechanism of such mixed enterprises is similar to that of the non-state-owned enterprises. This paper compared the economic efficiency difference between stateowned enterprises and non-state-owned enterprises from the aspects of capital allocation efficiency, TFP and spillover effects, so as to study the main mechanism of SOEs reform affecting economic growth.

\subsection{SOEs Reform and Capital Allocation Efficiency}

In the China Statistical Yearbook, the firm's data is not comprehensive. Based on the available data, capital productivity is represented with capital output ratio, incremental capital-output ratio (ICOR) and marginal capital output. Table 1 is the data of capital output ratio, incremental capital-output ratio (ICOR) and marginal capital output from 1997 to 2016, as well as comparison of capital productivity of stateowned enterprises and private industrial enterprises.

Table 1. Capital Productivity of State-owned and Private Industrial Enterprises

\begin{tabular}{lcccccc}
\hline \multirow{2}{*}{ year } & \multicolumn{2}{c}{ State-owned Enterprise } & \multicolumn{3}{c}{ Private Enterprise } \\
\cline { 2 - 7 } 1998 & Capital Output Ratio & ICOR & MPK & Capital Output Ratio & ICOR & MPK \\
\cline { 2 - 6 } 1999 & 19.27 & - & 0.03 & 10.27 & - & 0.87 \\
2000 & 18.74 & 25.15 & 0.04 & 9.52 & 10.34 & 0.65 \\
2001 & 17.18 & 14.60 & 0.04 & 9.31 & 10.85 & 0.46 \\
2002 & 16.98 & 35.21 & 0.04 & 9.13 & 10.53 & 0.30 \\
2003 & 15.44 & 11.13 & 0.05 & 8.30 & 8.85 & 0.24 \\
2004 & 13.76 & 9.32 & 0.05 & 8.19 & 9.83 & 0.19 \\
2005 & 12.54 & 9.40 & 0.06 & 8.05 & 9.68 & 0.14 \\
2006 & 11.92 & 13.79 & 0.07 & 7.44 & 8.66 & 0.14 \\
2007 & 11.83 & 16.08 & 0.07 & 7.02 & 8.48 & 0.13 \\
2008 & 11.15 & 11.78 & 0.08 & 6.01 & 5.68 & 0.13 \\
2009 & 11.12 & 22.15 & 0.09 & 5.72 & 6.60 & 0.11 \\
2010 & 13.02 & 175.18 & 0.08 & 6.39 & 20.56 & 0.10 \\
2011 & 11.72 & 9.76 & 0.09 & 6.43 & 9.61 & 0.09 \\
2012 & 11.27 & 16.66 & 0.10 & 5.89 & 8.79 & 0.10 \\
2013 & 11.06 & 16.32 & 0.10 & 5.86 & 9.51 & 0.10 \\
2014 & 11.33 & 23.48 & 0.11 & 6.28 & 11.23 & 0.08 \\
2015 & 12.72 & 164.23 & 0.10 & 6.61 & 25.12 & 0.08 \\
2016 & 12.33 & 16.42 & 0.10 & 5.82 & 6.03 & 0.09 \\
\hline & 12.19 & 20.04 & 0.10 & 5.18 & 5.95 & 0.10 \\
\hline
\end{tabular}

Data Source: China Statistical Yearbook and the author calculation

According to Table 1, from 1998 to 2016, the capital output ratio in industrial enterprises has a downward trend in general, which may attribute to technology progress in the process of capital deepening, while the last two years has a downward trend. Besides, the ICOR of state-owned is almost twice as much as that of private industrial enterprises all the time. Particularly in 2009, both state-owned enterprises and private enterprises had a large irrational increase in investment, which affect the following economic performance of both two. The reason may be that because of the unique financial discrimination in China the private enterprise has to improve capital efficiency so as to achieve more profits, while the state-owned enterprise with low capital cost used to concern about the economic scale 
rather than the economic profit. Although scale of investment in both state-owned enterprises and private enterprises continues to grow, the marginal capital output has different performance. The former continues to grow, while the latter falls. It means that with the growth of economic scale the technology progress in state-owned enterprises is significant, while the opposite performance in private enterprises. Therefore, the ways of promoting economic growth not only requires the government to accelerate SOEs reform and improve capital productivity efficiency of state-owned enterprises, but also to eliminate private enterprise financing discrimination and to promote technology advancement of "learn by doing" in the process of capital deepening.

\subsection{SOEs Reform and Total Factor Productivity}

Existing literatures thought the improvement of TFP of SOEs reform was an important channel for promoting economic growth. This paper, due to the limit of data, only calculates and compares the TFP of the state-owned and private industrial enterprises. Figure 1 shows that the trend of the TFP of the state and private industrial enterprises from 1998 to 2016. Different from the previous studies, this paper finds that from 1998 to 2007, the TFP of the state-owned industrial enterprises kept increasing compared to the based year 1998. On the other hand, private industrial enterprises firstly had a downward trend but begun to increase from 2004. Overall, private enterprises have a lower TFP than that of state-owned industrial enterprises all the time. It may show that the SOEs reform had a significant positive effect on productivity improvement during the period, "Grasp the large, let go of the small" makes more lowefficiency small state-owned enterprises quit the market, and also private industrial enterprises were lack of technology progress of learn by doing in the process of capital deepening. Then from 2009, they both had a downward trend, which may be caused by Four Trillion Investment. In order to response to the global financial crisis, the government let the majority of Four Trillion Investment flow into state-owned enterprises. This decision not only changed the trend of productivity improvement of state-owned industrial enterprise, but also burdened the financing cost of private industrial enterprise and caused the downward of productivity improvement of private industrial enterprise. Therefore, promoting economic growth requires the government to accelerate SOEs reform and improve innovation of state-owned enterprises, and at the same time promote the progress of the technology advancement of "learn by doing" in the process of capital deepening.

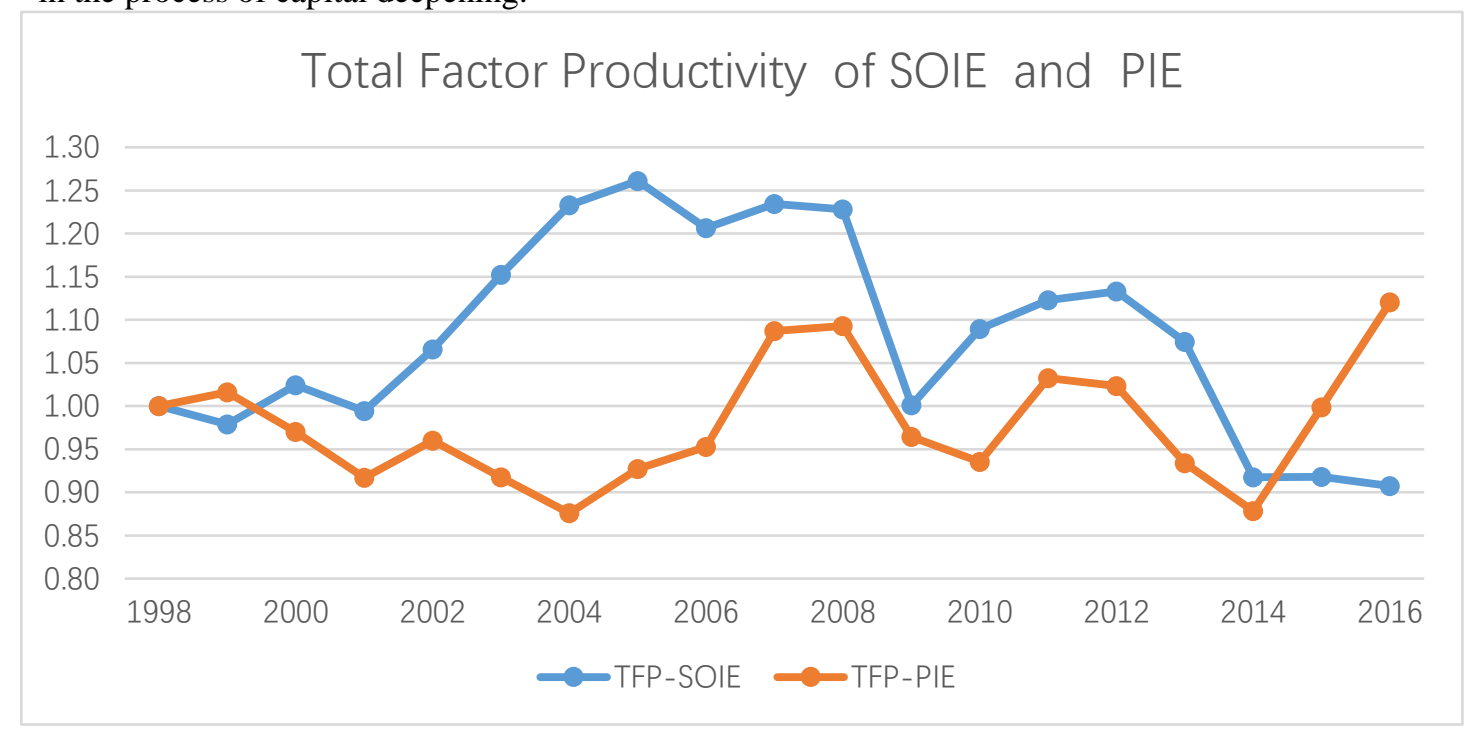

Figure 1. The compare of total factor productivity of SOIE and PIE

\subsection{SOEs Reform and External Spillover Effect on Other Enterprises}

The enterprise agglomeration and the following economic scale will have an external spillover effect on other enterprises. The effect comes mainly from two aspects, one is the imitation effect of 
technology and management with the number of enterprises in same industry increased; second, the improvement of productivity efficiency in the process of production with the number of enterprises in different industries increased, especially in the upstream industry. However, in China, due to the differences in the mode of operation and management between state-owned enterprises and private enterprises, the external spillover effect of enterprises is also different. At present, the external spillover effect of state-owned enterprises on other enterprises is significantly lower than that of non-state-owned enterprises. Moreover, if 5\% of state-owned enterprises to reform annually, economic growth would be increased by $0.33 \%$; if $10 \%$ or $20 \%$ of state-owned enterprises to reform annually, the economic growth rate can be increased by $0.47 \%$ or $0.50 \%$ (Xu et al., 2014). Therefore, the SOEs reform can not only improve the production efficiency itself (internal effects), but also bring positive external effects on other enterprises (Liu and Shi, 2010), which will be the third effect of SOES reform causes to economic growth.

\section{SOEs Reform and Privatization}

Through the above analysis, it can be learned that the capital allocation efficiency among stateowned enterprises. Although capital allocative efficiency is higher in private enterprises, their progress of technological advancement cannot catch up their expanding share in economy. Therefore, the core of current economic reform is still the SOEs reform., also improve the technology progress of private enterprise. But about the way of SOEs reform is controversial all the time. For a long time, many liberal economists argue that public ownership is incompatible with the market economy and SOEs reform requires the enterprises be privatized. Support for the privatization of SOEs continue to rise, but whether privatization is the only way out of SOEs reform is questionable.

First, measuring the efficiency of SOEs cannot simply rely on the output, profit and input-output ratio, but from a comprehensive consideration of the leading and pillar role SOEs in the national economy. It should also take in to consideration of the current and long-term influence of SOEs on the various sectors of the national economy. That is to observe its total input-output ratio. At present, China is still in the primary stage of socialism. SOEs still play an irreplaceable role in the current economic development of China, while maintaining social stability, safeguarding national security, realizing national strategy, and promoting independent innovation. Contrarily, as private enterprises prefer to invest for the short-term gains, they are often reluctant to choose or bear industrial projects with high risk factor and long capital recovery cycle. Vigorously developing SOEs is an inherent requirement of the nature of China's political environment.

Second, the socialist economy with Chinese characteristics requires us to uphold the common development of public ownership as the main body and coexistence of various forms of ownership. Insisting the leading role of state-owned economy, maintaining the strong control, and the influence of state-owned economy on the whole economy, are the basic features of public ownership as the main body. The SOEs reform should help to play the leading role of state-owned economy. It is mainly manifested in two aspects. On the one hand, the state-owned economy can control and influence the operation of the national economy and guide the national economy to the pre-direction of development. Besides, state-owned economy plays an important role in maintaining macroeconomic stability, avoiding large fluctuations and promoting industrial restructuring. On the other hand, the state-owned economy can play a guiding role in the common development of various ownership economies and guide the nonpublic economy to the direction conducive to socialism through various forms, including the development of mixed ownership. Establish and improve the socialist market economic system, combine the superiority of the socialist system with the vitality of the market economy.

Third, state ownership is not only a form of "owned, managed, and profit by nation", but can also be in other forms. Market economy requires market operators to operate independently, self-finance 
according to the market supply and demand changes in the autonomy to make business decisions, and bear the corresponding economic responsibility. As long as the state-owned enterprises become economic entities in accordance with market rules for business. Then public ownership, state-owned enterprises can be combined with the market economy. Since the reform and opening up, China's SOEs have made great progress in reform and development. In general, they have already merged with the market economy to a great extent. The quality and efficiency of operation have been improved obviously. A number of key enterprises with strong competitiveness have been playing an active part in the domestic and international market competition. They have made a significant contribution to economic and social development, enhancing China's comprehensive strength.

Last but not least, in the 1980s, under the influence of the neoliberalism, the SOEs reform of the former Soviet Union and Eastern European countries was eager to pursue privatization, which brought an unprecedented economic catastrophe. It not only directly resulted to the Soviet Union's economic downturn of 1990s, but also had some negative influence on the long term economic performance. While the means of production and social wealth common possessed by all the people were concentrated in the minority, most of the national capital was controlled by international capital. The result of the concentration of social wealth is that socialism economy gradually evolves into capitalist economy through the process of privatization. The loss of the independence of national capital results to the colonization of national economy and the loss of the ability of the government to interfere the healthy development of the national economy. The ultimate consequence of privatization is the polarization between the rich and the poor. After many SOEs transforming into private enterprises, because of the pursuit of efficiency, they will substantial reduction of staff and lower welfare standards, leading to serious unemployment and exacerbate social instability. SOEs as the only powerful market entities have the ability to compete with the multinational corporations under the control of international monopoly capital, once follow the privatization of Soviet Union Eastern Europe will be the "economic vassal state" controlled by international monopoly capital, economic sovereignty, and even political sovereignty will be a serious threat. Therefore, SOEs reform in China should not be simplified as privatization. There should also be an emphasis on the dual development of public ownership as the main body and coexistence of various forms of ownership.

\section{Conclusion}

In summary, the success of SOE reforms in China will primarily depend on establishing a balanced and level playing field for SOEs and private sector firms to compete with each other. The government will need to incrementally reduce its interference in the corporate sector in favor of a new culture that champions efficiency and profitability. The success of China's goal to restructure its economy will depend on the SOE reform working alongside other reforms such as liberalizing interest rate liberalization, improving the pricing mechanism of key resources and other institutional arrangements. SOEs have always played a dominant role in China's economy. They are protected by market entry restrictions severing off potential competition from non-state-owned firms in a myriad of strategic industries. Furthermore, they often received government subsidies in forms of low effective tax rates, low dividend payouts, and little or no royalties on resource extraction. The favorable position of SOEs in accessing bank credit substantially crowds out other entities that need capital. As a result, SOEs received around 85\% of bank loans in China in 2009, while a report released on the 2013 Boao Forum revealed that $62 \%$ of the small and medium enterprises (SMEs) did not have any access to bank loans. SOEs have remained largely inefficient in spite of ongoing reforms in the past three decades. They are blamed for extracting capital and raw materials without yielding efficient returns. Private firms are more than twice as profitable as SOEs in terms of return on assets (ROA). Out of the eight listed companies 
of Cofco, five either lost money or reported lower profits. Four out of six subsidiaries of SDIC also experienced the same problem. On top of this, SOEs have a high leverage ratio of $65 \%$, which is above the $40-60 \%$ range private investors find acceptable. Invigorating China's SOEs is easier said than done. The government appoints board directors and chief executives. Senior staff rotations between government and SOE positions are common practices. In some cases, heads of SOEs are also members or alternates of the Chinese Communist Party Central Committee. Such organizational complexity represents a serious hindrance in reforming the SOEs which the government is seeking to address with its anti-corruption program. According to the prevailing school of thought, changing the formal ownership structure of SOEs would address the above problem. Experiences with reforms in the past two decades, however, proved otherwise. SOEs performed better when they were given the right incentive structure while subjected to a degree of market competition. Opening up SOEs to more private capital thus may not mean much in the beginning. SOEs will achieve more success if they are granted more autonomy to make managerial decisions, in consultation with the market, to identify comparative advantages for the firm. The gradual and yet deterministic approach taken by the Chinese government to reform SOEs by granting them more autonomy is clearly a promising start. If history is any guide, productivity of SOEs usually improves with more autonomy, but this is not necessarily accompanied by increased profitability. In many cases, managers abused the higher autonomy by making discretionary decisions to boost wages, fringe benefits and unauthorized expenditures. The central government has responded by dispatching disciplinary teams to monitor against such abuses, while staying mindful not to roll back the reform process by discouraging autonomy and returning to regulation.

At present, China is promoting further deepen economic reform, and the core of current economic reform is still the SOEs reform. But about the way of SOEs reform is controversial all the time. Now more and more voices support the privatization of state-owned enterprises in order to improve the capital allocation efficiency. While, SOEs reform in China never equals to privatization. In order to find a suitable way for China's SOEs reform. This paper firstly reviewed the process of SOEs reform since reform and opening up, and then studied the mechanism of how state-owned enterprise reform influences economic growth, and distinguished the capital allocation efficiency between state-owned and private enterprises. The results show that: 1) the capital allocation efficiency among state-owned enterprises is low, and the productivity of stated-owned enterprises cannot be fully released, which is an important reason for the capital allocation efficiency of state-owned enterprises is lower than private enterprises; 2) although the capital allocation efficiency is higher in private enterprises, its improvement speed is behind its share increase in economy. In the condition of poor allocation of private sector, blindly promote the reform of property rights of state-owned enterprises cannot effectively alleviate the problem of efficiency losses. State-owned enterprise reform can boost economic growth by increasing capital marginal output, improving capital dynamic allocation efficiency, promoting TFP growth and exerting external spillovers on other firms. At present, China is exploring the endogenous power of economic growth, improving the market institutions, promoting the state-owned enterprises reform with positive and steady pace and the re-allocation within private sector, which has significant influence on improving economic efficiency and promoting sustained economic growth.

\section{Acknowledgments}

I am grateful to anonymous referee and the editor for insightful comments on previous versions which substantially improved this article. Besides, I am also so grateful for the Social Science Foundation of Shanghai under grant No.2017BJL003. The usual disclaimer applies.

\section{Reference}


[1] Ackerberg, D. A., Caves, K., \& Garth Frazer. 2015. Identification Properties of Recent Production Function Estimators. Econometrica, Vol.83(06), 2411-2451.

[2] Bai C E, Lu J, Tao Z. 2006, An Empirical Study on the Effects of Ownership Reform in China. Economic Research Journal, (08), 4-13

[3] Bai C E, Lu J, Tao Z. 2006, The Multitask Theory of State Enterprise Reform: Empirical Evidence from China. American Economic Review, 96(2):353-357.

[4] Brandt, L., Van Biesebroeck, J., and Zhang, Y., 2012, “Creative Accounting or Creative Destruction? Firm-Level Productivity Growth in Chinese Manufacturing”, Journal of Development Economics, Vol.97(02), 339-351

[5] Hu Y, Min S, Junxi Z. 2006, Does Privatization Work in China? Economic Research Journal, (07), 49-60

[6] Hsieh C-T and Klenow P J, 2009, Misallocation and Manufacturing TFP in China and India. The Quarterly Journal of Economics, Vol. 124, 1403-1448

[7] Hsieh C-T and Song Z M, 2015. Grasp the large, let go of the small: the transformation of the state sector in China. National Bureau of Economic Research

[8] Liu X. 2004. The Effects of Privatization on Industrial Performance in Chinese Economic Transition-Analysis of the 2001 National Industrial Census data. Economic Research Journal, (08), 16-26

[9] Liu Y M, Shi L. 2010, The Dual Efficiency Loss of State-Owned Enterprises and Economic Growth. Economic Research Journal, (1):127-137

[10] Mu J L. 2012. The Comparison Analysis of Productive Efficiency between State-owned and Non-state-owned Industry Enterprises-based on 2008 China Economic Census Data. Economic Survey, Vol.1(03), 55-59.

[11] Midrigan V and Xu Y, 2014, Finance and Misallocation, American Economic Review, Vol.104, 422-458

[12] Song, Z., Storesletten, K., and Zilibotti, F., 2011, “Growing like China”, American Economic Review, Vol.101(01), 196-233

[13] Tong S Y. 2009, Why privatize or why not? Empirical evidence from China's SOEs reform. China Economic Review, Vol.20(3):402-413.

[14] Wu Y B. 2015, Restudying the Dual Efficiency Losses of Chinese State-owned Enterprises. Modern Economic Science, (01), 124-128

[15] Xu Z Y, H C, Lai Y W.2014, Industrial Supporting Capabilities and Productivity. Research on Economic and Management, (07):74-84.

[16] Xu Z Y, Zhang W K. 2015, SOEs Reform's Impact on Economic Growth. Economic Research Journal, (04), 122-135

[17] Zhong N H, Liu Z K, He J X and Su C L. 2016. The Structural Problem of China's Non-financial Corporate Debt. Economic Research Journal, (07), 102-117

[18] Zhang T H, Zhang S H. 2016, Biased Policy, Resource Allocation and Aggregate Productivity. Economic Research, (2): 126139. 